\title{
Catalogue of Bibionidae (Diptera: Bibionomorpha) types housed in the collection of the Museu de Zoologia da Universidade de São Paulo, Brazil
}

\author{
Rafaela Lopes Falaschi'; Sarah Siqueira Oliveira² \& Carlos José Einicker Lamas ${ }^{3,4}$ \\ 1 Universidade Estadual de Ponta Grossa (UEPG), Departamento de Biologia Estrutural, Molecular e Genética, Programa de Pós-Graduação em \\ Biologia Evolutiva. Ponta Grossa, PR, Brasil. ORCID: 0000-0002-3046-5744. E-mail: rlfalaschi@gmail.com (corresponding author) \\ 2 Universidade Federal de Goiás (UFG), Instituto de Ciências Biológicas (ICB), Departamento de Ecologia (DECOL), Programa de Pós-Graduação \\ em Biodiversidade Animal (PPGBAN). Goiânia, G0, Brasil. ORCID: 0000-0002-9453-4569. E-mail: oliveira.sarahcv@gmail.com \\ ${ }^{3}$ Universidade de São Paulo (USP), Museu de Zoologia (MZUSP). São Paulo, SP, Brasil. ORCID: 0000-0002-7750-590X. E-mail: einicker@usp.br \\ ${ }^{4}$ Conselho Nacional de Desenvolvimento Científico e Tecnológico (CNPq), fellowship.
}

\begin{abstract}
Following a recommendation of the International Code of Zoological Nomenclature, this paper provides a catalogue of the type specimens of Bibionidae (Diptera: Bibionomorpha) held in the collection of the Museu de Zoologia da Universidade de São Paulo, Brazil (MZUSP). Label data and the condition of 21 type specimens (two holotypes and 19 paratypes) of two Neotropical species is provided. Photographs of the male terminalia of the holotypes are also presented.
\end{abstract}

Key-Words. Nomenclature; Scientific collections; Taxonomy; Type material.

\section{INTRODUCTION}

Brazil is one of the most diverse countries in the world and its most important scientific collection is the Museu de Zoologia da Universidade de São Paulo (MZUSP), São Paulo, Brazil. This collection includes more than 8,000 species and six hundred thousand mounted specimens, being the largest and most important depository of Neotropical Diptera in Brazil and in South America. Additional information on the collection is available at www. mz.usp.br.

The family Bibionidae encompasses eight genera with over 700 described species in the world (Fitzgerald, 2009). The group classification includes four subfamílies; three monotypic, Hesperininae, Penthetriinae, and Pleciinae, and the last, Bibioninae, with five genera (Fitzgerald, 2009; Pinto \& Amorim, 2000). Eight genera and 169 species are known from the Neotropical

Table 1. Type specimens of Bibionidae held in the MZUSP, in alphabetical order of species epithet, with reference to the number of specimens, males, and females, for each type category.

\begin{tabular}{lcc}
\hline \multicolumn{1}{c}{ Species list } & Holotype & Paratype \\
\hline $\begin{array}{l}\text { Subfamily Bibioninae } \\
\text { Bibionellus barrettoi Lane \& Forattini, } 1948\end{array}$ & $10^{\pi}$ & $50^{7}, 79$ \\
Bibionellus paulistensis Lane \& Forattini, 1948 & $10^{7}$ & $30^{\circ}, 49$ \\
\hline
\end{tabular}

Region (Amorim et al., 2002). Catalogues of the Neotropical fauna of Bibionidae were presented by Hardy $(1959,1966)$ and Falaschi et al. (2016a).

Following a recommendation of the International Code of Zoological Nomenclature (ICZN, 1999: 72F.4), the present paper provides a catalogue with information on 21 type specimens (two holotypes and 19 paratypes) of two Neotropical species of the family Bibionidae, genus Bibionellus Edwards, held in the collection of the MZUSP (Table 1).

\section{MATERIALS AND METHODS}

The list given below is in alphabetical order of subfamily, genus, and epithet. Names, combinations, and spellings follow the catalogue of Bibionidae of the Americas south of the United States (Hardy, 1966). The standard for reproducing the information on the labels follows previous catalogues of general Diptera and Bibionomorpha housed in other major museums collections of Neotropical fauna (e.g., for the Museu de Zoologia da Universidade de São Paulo (MZUSP), Brazil (Fachin \& Lamas, 2015; Falaschi et al., 2016b; Mello \& Lamas, 2011)). All types listed here are drypinned specimens. High-resolution photographs will be subsequently provided for most primary types at MZUSP's homepage (www.mz.usp.br). 

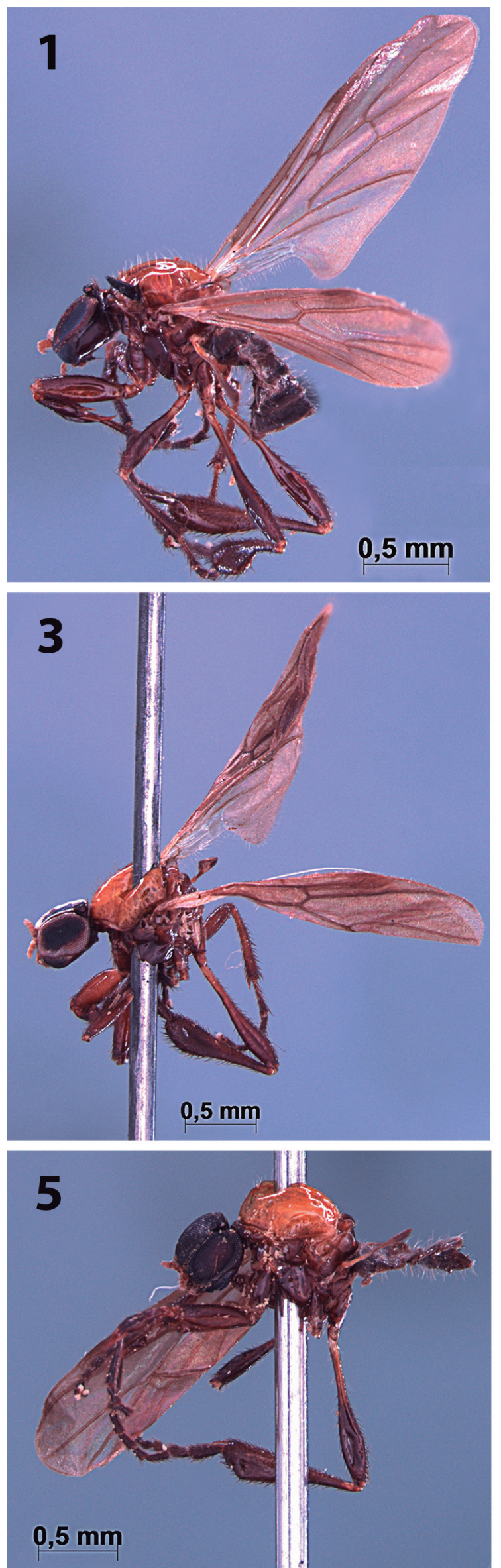
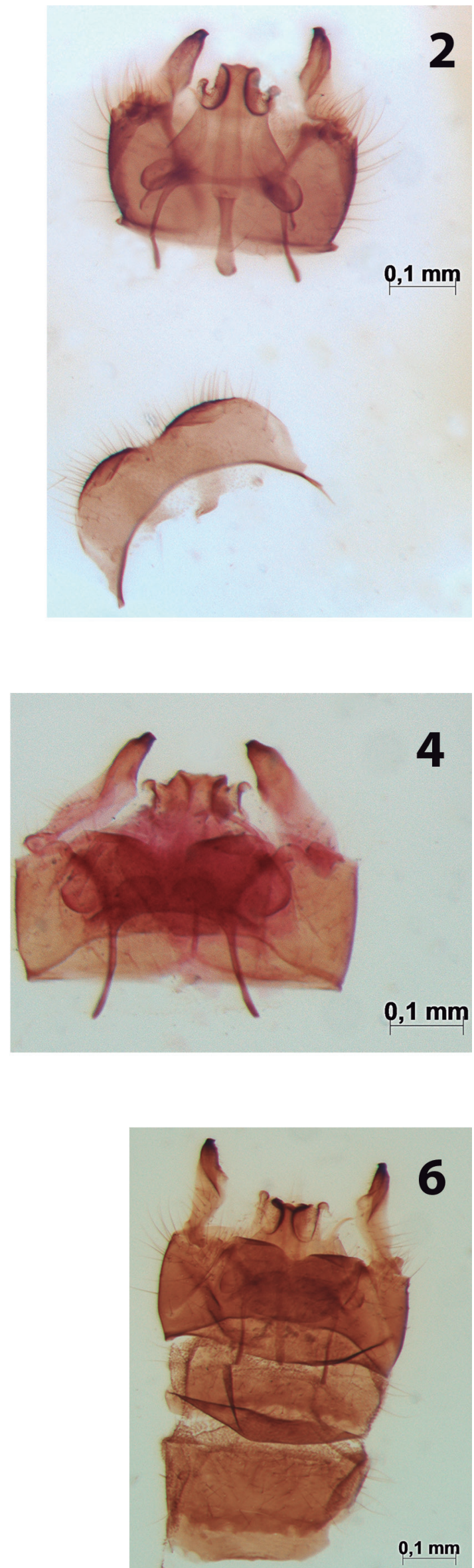

Figures 1-6. (1-2) Bibionellus barrettoi, holotype male, Corumbá de Goiás, Goiás State, Brazil. (1) habitus; (2) male terminalia. (3-4) Bibionellus paulistensis, holotype male, Pitangueiras, São Paulo State, Brazil. (3) habitus; (4) male terminalia. (5-6) Bibionellus paulistensis, paratype male, Porto Cabral, São Paulo State, Brazil. (5) habitus; (6) male terminalia. 


\section{RESULTS}

\section{Subfamily Bibioninae Fleming, 1821}

\section{Bibionellus barrettoi Lane \& Forattini, 1948 (Figs. 1-2)}

Lane \& Forattini, 1948: 569 (original description), figs. 1-2 (male genitalia). Ref. Hardy, 1953: 344 (identification key).

Type locality: Brazil, Goiás, Corumbá de Goiás.

Holotype $\sigma^{\pi}$ with labels: (1) printed on pink paper: "HOLOTIPO"; (2) handwritten on white paper: "XI.45 [xi.1945] | Goiaz [Goiás] | Corumbá [Corumbá de Goiás] | Barretto col."; (3) printed with handwritten inscriptions on white paper: "Bibionellus | barrettoi | det. John Foratini Lane 1948".

Condition of type: Pinned, terminalia on separate permanent slides (Figs. 1 and 2). Missing parts: None.

Paratype $q$ with labels: (1) printed on pink paper: "ALOTIPO"; (2) printed on white paper: "11-945 [xi.1945] | Est. de Goiás | Corumbá [Corumbá de Goiás] |F. Monjolinho| Barretto col.".

Condition of paratype: Pinned. Missing parts: None.

Paratype $q$ with labels: (1) printed on pink paper: "PARATIPO"; (2) handwritten on white paper:"XI.45 [xi.1945]| Goiaz [Goiás] | Corumbá [Corumbá de Goiás] | Barretto col."; (3) printed with handwritten inscriptions on white paper: "Bibionellus | barrettoi | det. John Forattini Lane 194".

Condition of paratype: Pinned. Missing parts: Antennae.

Paratype $q$ with labels: (1) printed on pink paper: "PARATIPO"; (2) printed with handwritten inscriptions on white paper: "XI.45 [xi.1945] | Goiaz [Goiás] | Corumbá [Corumbá de Goiás] | Barretto col."; (3) printed with handwritten inscriptions on white paper: "Bibionellus | barrettoi | det. John Foratini Lane 1948".

Condition of paratype: Pinned, left wing on separated permanent slides. Missing parts: None.

Paratype $\$$ with labels: (1) printed on pink paper: "PARATIPO"; (2) handwritten on white paper:"XI.45 [xi.1945]| Goiaz [Goiás] | Corumbá [Corumbá de Goiás] | Barretto col."; (3) printed with handwritten inscriptions on white paper: "Bibionellus | barrettoi | det. John Forattini Lane 1948".

Condition of paratype: Pinned. Missing parts: None.

Paratype $\sigma^{x}$ with labels: (1) printed on pink paper: "PARATIPO"; (2) handwritten on pink paper:" $0^{\text {"1"; }}$ (3) handwritten on white paper: "XI.45 [xi.1945] | Goiaz [Goiás] | Corumbá [Corumbá de Goiás] | Barretto col."; (4) handwritten on yellow paper: "D|D".
Condition of paratype: Pinned, terminalia on separated permanent slides. Missing parts: Antennae.

Paratype $\sigma^{7}$ with labels: (1) printed on pink paper: "PARATIPO"; (2) handwritten on pink paper:" $\sigma^{\prime \prime}$; (3) handwritten on white paper: "XI.45 [xi.1945] | Goiaz [Goiás] | Corumbá [Corumbá de Goiás] | Barretto col."; (4) printed with handwritten inscriptions on white paper: "Bibionellus | barrettoi | det. John Foratini Lane 1948"; (5) handwritten on yellow paper: "I".

Condition of paratype: Pinned, terminalia on separated permanent slides. Missing parts: None.

Paratypes $\sigma^{x}$ and $\%$ with labels: (1) printed on pink paper: "PARATIPO"; (2) handwritten on white paper:"XI.45 [xi.1945]| Goiaz [Goiás] | Corumbá [Corumbá de Goiás] | Barretto col."; (3) printed with handwritten inscriptions on white paper: "Bibionellus | barrettoi | det. John Forattini Lane 1948".

Condition of paratypes: Couple of flies pinned together, male terminalia on separated permanent slides. Missing parts: Male antennae.

Paratypes $\sigma^{x}$ and $\$$ with labels: (1) printed on pink paper: "PARATIPO"; (2) handwritten on white paper: "XI.45 [xi.1945] | Goiaz [Goiás] | Corumbá [Corumbá de Goiás] | Barretto col."; (3) printed with handwritten inscriptions on white paper: "Bibionellus | barrettoi | det. John Foratini Lane 1948"; (4) handwritten on yellow paper: "II".

Condition of paratypes: Couple of flies pinned together, male terminalia on separated permanent slides. Missing parts: None.

Paratypes $\sigma^{\prime}$ and $\$$ with labels: (1) printed on pink paper: "PARATIPO"; (2) handwritten on white paper: "XI.45 [xi.1945] | Goiaz [Goiás] | Corumbá [Corumbá de Goiás] | Barretto col."; (3) printed with handwritten inscriptions on white paper: "Bibionellus | barrettoi | det. John Foratini Lane 1948"; (4) handwritten on yellow paper: "III".

Condition of paratypes: Couple of flies pinned together, male terminalia on separated permanent slides. Missing parts: None.

Comments: According to Lane \& Forattini 1948: 569 there is another pair of paratypes of B. barrettoi, from Pitangueiras, state of São Paulo, which was not found at the collection and there is no record of a loan.

\section{Bibionellus paulistensis Lane \& Forattini, 1948 (Figs. 3-6)}

Lane \& Forattini, 1948: 571 (original description); figs. 3-4 (male genitalia). Ref. Hardy, 1953: 344 (identification key).

Type locality: Brazil, São Paulo, Pitangueiras. 
Holotype $\sigma^{7}$ with label: (1) printed on pink paper: "HOLOTIPO"; (2) printed with handwritten inscriptions on white paper: " $x-943$ [x.1943] | SÃO PAULO | Pitangueiras | F.Lane"; (3) printed with handwritten inscriptions on white paper:"Bibionellus | paulistensis | det. John Forattini Lane 1948".

Condition of type: Pinned, terminalia on separated permanent slides (Figs. 3 and 4). Missing parts: None.

Paratype $\$$ with labels: (1) printed on pink paper: "ALOTIPO"; (2) printed with handwritten inscriptions on white paper: "x-943 [x.1943] | SÃO PAULO | Pitangueiras | F.Lane".

\section{Condition of paratype: Pinned. Missing parts: None.}

Paratype $\$$ with labels: (1) printed on pink paper: "PARATIPO"; (2) printed with handwritten inscriptions on white paper: " $x-943$ [x.1943] | SÃO PAULO | Pitangueiras | F.Lane"; (3) printed on white paper: "Bibionellus | paulistensis".

Condition of paratype: Pinned. Missing parts: Antennae.

Paratype $q$ with labels: (1) printed on pink paper: "PARATIPO"; (2) printed with handwritten inscriptions on white paper: "x-943 [x.1943] | SÃO PAULO | Pitangueiras | F.Lane"; (3) printed with handwritten inscriptions on white paper:"Bibionellus | paulistensis | det. John Forattini Lane 1948".

\section{Condition of type: Pinned. Missing parts: Antennae.}

Paratype $\&$ with labels: (1) printed on pink paper: "PARATIPO"; (2) printed with handwritten inscriptions on white paper: "x-943 [x.1943] | SÃO PAULO | Pitangueiras | F.Lane"; (3) printed with handwritten inscriptions on white paper:"Bibionellus | paulistensis | det. John Forattini Lane 1948".

Condition of paratype: Pinned. Missing parts: None.

Paratype $\sigma^{\top}$ with labels: (1) printed on pink paper: "PARATIPO"; (2) printed with handwritten inscriptions on white paper: " $x$-943 [x.1943] | SÃO PAULO | Pitangueiras | F.Lane"; (3) printed with handwritten inscriptions on white paper:"Bibionellus | paulistensis | det. John Forattini Lane 1948"; (4) handwritten on yellow paper: "IV".

Condition of paratype: Pinned, terminalia on separated permanent slides. Missing parts: Head.

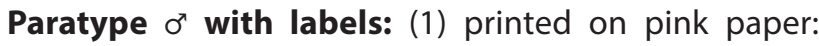
"PARATIPO"; (2) printed with handwritten inscriptions on white paper: " $x$-943 [x.1943] | SÃO PAULO | Pitangueiras | F.Lane"; (3) printed with handwritten inscriptions on white paper: "Bibionellus | paulistensis | det. John Forattini Lane 194"; (4) handwritten on yellow paper: “E |E".
Condition of paratype: Pinned, terminalia on separated permanent slides. Missing parts: Head.

Paratype $\sigma^{\prime \prime}$ with labels: (1) printed on pink paper: "PARATIPO"; (2) printed on white paper: "BRASIL S.PAULO [São Paulo] | PORTO CABRAL | RIO PARANÁ | L.Travassos Filho col. | 6-15/X/1941"; (3) printed on white paper: "61080"; (4) printed on white paper: "Bibionellus paulistensis | Lane \& Forattini, 1948| Det. Falaschi, Oliveira \& Lamas viii.2017".

Condition of paratype: Pinned, terminalia and right wing on separated permanent slides (Figs. 5 and 6). Missing parts: Mid legs and right hind leg.

Comments: This paratype did not originally have an identification label. According to Lane \& Forattini 1948: 571 there is a paratype from Porto Cabral, state of São Paulo, collected by Travassos Filho, Carrera, and Dente, in x.1941. We analyzed the specimen and, in spite of some intraspecific color variation, it is a male specimen belonging to the species $B$. paulistensis. Hence, even in the absence of the identification label, we listed it together with the type-series of $B$. paulistensis and added a new identification label (label 4 previously listed). Our decision was based on the analysis of the shape of the parameres and the mesosome (including its lateral lobes and median and lateral projections), the presence of setae at the base of the gonocoxite, and the absence of long setae at the apex of the gonocoxite (Figs. 4 and 6 ). It is worth of note that a revision and phylogeny of the genus Bibionellus, including an identification key and illustration of all Bibionellus species known was done by Pinto \& Amorim (1997).

\section{REMARKS}

According to Lane \& Forattini (1948: 571), the holotype and nine paratypes of $B$. barrettoi, including the allotype, were deposited at the "Faculdade de Saúde Pública" (FSP-USP) and the remainder of the type-series were housed at the Museu de Zoologia (MZUSP). Lane \& Forattini did the same with the type-series of $B$. paulistensis, establishing that the holotype, allotype, and two paratypes would be deposited at the FSP-USP and the remainder of the type-series would be housed at the MZUSP (Lane \& Forattini, 1948: 573). However, since the beginning of the 1970s, the complete type-series is deposited at the MZUSP.

John Lane was a professor at the Department of Parasitology of the "Faculdade de Saúde Pública" (School of Public Health) of Universidade de São Paulo where he started the Laboratory of Entomology and an insect collection focused on Culicidae and other nematocerous flies. In 1970, the Department of Parasitology was transferred to the Institute of Biomedical Sciences and the entomological collection of John Lane was moved to the Museu de Zoologia (MZUSP), except for the Culicidae and other families of nematocerous flies of medical importance, which were kept in the Faculdade de Saúde 
Pública. Hence, the MZUSP is the depository of the types previously located at the FSP-USP.

\section{ACKNOWLEDGMENTS}

We are thankful to Camila Conti and Paula Rodrigues (Museu de Zoologia da Universidade de São Paulo, São Paulo, Brazil) for help with information on some type specimens of Bibionidae and to Scott Fitzgerald for help with the literature. Along the preparation of this paper, RLF benefited from FAPESP grant (2013/16524-9), SSO from CNPq (428471/2016-1), and CJEL from CNPq (304512/2016-8).

\section{REFERENCES}

Amorim, D.S.; Silva, V.C. \& Balbi, M.I.P.A. 2002. Estado do conhecimento dos Diptera neotropicais. In: Costa, C.; Vanin, S.A.; Lobo, J.M. \& Melic, A. (Eds.). Proyecto de Red Iberoamericana de Biogeografia y Entomología Sistemática, PRIBES 2002. Zaragoza, Sociedad Entomológica Aragoneza y CYTED. p. 29-36.

Fachin, D.A. \& Lamas, C.J.E. 2015. A catalogue of the types of Stratiomyidae (Diptera: Brachycera) in the collection of the Museu de Zoologia da Universidade de São Paulo, Brazil. Zootaxa, 3918(3): 406-414.

Falaschi, R.L.; Oliveira, S.S. \& Amorim, D.S. 2016a. Family Bibionidae. Zootaxa, 4122: $20-25$

Falaschi, R.L.; Oliveira, S.S. \& Lamas, C.J.E. 2016b. Catalogue of Anisopodidae (Diptera: Bibionomorpha) types housed in the collection of the Museu de Zoologia da Universidade de São Paulo, Brazil. Revista Brasileira de Entomologia, 60: 24-29. D01
Fitzgerald, S.J. 2009. Bibionidae (March flies, Love-bugs). In: Brown, B.V.; Borkent, A.; Cumming, J.M.; Wood, D.M.; Woodley, N.E. \& Zumbado, M.A. (Eds.). Manual of Central American Diptera. Ottawa, NRC Research Press. v. 1, p. 245-251.

Fleming, J. 1821. Insecta. In: Stewart, Dugald, Playfair, John \& Brande, W.T. Supplement to the fourth, fifth and sixth editions of the Encyclopedia Britannica. Edinburgh, A. Constable \& Co., [1815]-1824. v. 5, pt. 1, p. 41-56.

Hardy, D.E. 1953. The Argentine Bibionidae (Diptera). Acta Zoologica Lilloana, 12: $343-376$.

Hardy, D.E. 1959. Catalogue of the Neotropical Bibionidae (Diptera, Nematocera). Acta Zoologica Lilloana, 17: 437-476.

Hardy, D.E. 1966. 18. Family Bibionidae. In: Papavero, N. (Ed.). A catalogue of the Diptera of the Americas south of the United States. São Paulo, Departamento de Zoologia da Secretaria da Agricultura do Estado de São Paulo. p. 1-20.

International Commission of Zoological Nomenclature (ICZN). 1999. International Code of Zoological Nomenclature. Fourth edition. London, The International Trust for Zoological Nomenclature, The Natural History Museum. xxx +306p.

Lane, J. \& Forattini, O.P. 1948. Duas Novas Especies de Bibionellus Edwards, 1935 (Diptera, Bibionidae). Revista de Entomologia, 19: 569-574.

Mello, R.L. \& Lamas, C.J.E. 2011. A catalogue of types of Conopoidea, Diopsoidea, Nerioidea and Tephritoidea (Diptera, Schizophora) in the collection of the Museu de Zoologia da Universidade de São Paulo. Revista Brasileira de Entomologia, 55(2): 187-205.

Pinto, L.G. \& Amorim, D.S. 1997. Taxonomy and phylogeny of the Neotropical genus Bibionellus (Diptera, Bibionidae). Iheringia Série Zoologia, 83: 65-84.

Pinto, L.G. \& Amorim, D.S. 2000. Bibionidae (Diptera: Bibionomorpha). Morfologia e análise filogenética. Ribeirão Preto, Holos, 98p. 